\title{
Do venture capitalists really invest in good industries? Risk-return perceptions and path dependence in the emerging European energy VC market
}

\section{Rolf Wüstenhagen*}

Institute for Economy and the Environment (IWÖ-HSG)

University of St. Gallen, Tigerbergstrasse 2

CH-9000 St. Gallen, Switzerland

E-mail: rolf.wuestenhagen@unisg.ch

*Corresponding author

\section{Tarja Teppo}

Helsinki University of Technology

PL 9500, FIN-02015 TKK, Finland

E-mail: tarja.teppo@hut.fi

\begin{abstract}
Venture Capital (VC) plays an important role in the commercialisation of innovation. Sectors like information and communication technologies and biotech account for two-thirds of all VC investments. Little attention has been paid to understanding how the venture capital market extends to new industries. Based on a survey of European energy technology VCs, we discuss the factors determining the emergence of a new market sector for VC investments. While there are sizeable investment opportunities, only $2-5 \%$ of all venture capital is invested in energy.

Three factors can help explain differences between energy and other more popular VC sectors:

- the perceived risk (market adoption risk, exit risk, technology risk, people risk, and regulatory risk) of investments in energy technologies

- the perceived returns in energy VC investments

- in an evolutionary perspective, the maturity of energy as a VC investment sector.
\end{abstract}

Keywords: Venture Capital (VC); innovation; renewable energy; technological change; path dependence.

Reference to this paper should be made as follows: Wüstenhagen, R. and Teppo, T. (2006) 'Do venture capitalists really invest in good industries? Risk-return perceptions and path dependence in the emerging European energy VC market', Int. J. Technology Management, Vol. 34, Nos. 1/2, pp.63-87.

Biographical notes: Dr. Rolf Wüstenhagen is Vice-Director of the Institute for Economy and the Environment at the University of St. Gallen, Switzerland. He has recently been a Visiting Professor at University of British Columbia in Vancouver, Canada. He teaches corporate sustainability, marketing, and innovation and technology management, with a particular focus on energy. His 
research focuses on the role of innovation for sustainable development, i.e., creating economic, environmental, and social value. Within the venture capital angle of this research, he investigates the role of financial and nonfinancial contributions by VCs to entrepreneurial firms commercialising new energy technologies. Another focus is on corporate venture capital as a means to introduce innovation in large incumbent firms of the energy sector. Prior to his current academic position, he worked for one of the leading European energy venture capital funds.

Tarja Teppo is PhD candidate at Helsinki University of Technology (HUT) and a Project Leader at HUT's Environmental Management Group. Previously, she held various positions within Nokia Corporation in Finland and the USA, most recently managing an internal venture at Nokia Ventures Organization. Her main research interests are sustainable entrepreneurship, venture capital, and corporate venturing.

"The myth is that venture capitalists invest in good people and good ideas. The reality is that they invest in good industries." (Zider, 1998)

"Energy is essential to economic and social development and improved quality of life. Much of the world's energy, however, is currently produced and consumed in ways that could not be sustained if technology were to remain constant and if overall quantities were to increase substantially." (UN, 1992)

\section{Introduction}

\subsection{Venture Capital (VC)}

Venture Capital (VC) can be defined as investment of long-term, risk equity finance by professional investors in new firms where the primary reward is eventual capital gain (Wright and Robbie, 1998). Venture capitalists do not only provide financial capital, but also take an active role in firm decision making. This is due to the specific situation of new ventures, which are characterised by high levels of uncertainty and information asymmetries between insiders and outsiders. Therefore, VCs are typically highly specialised in identifying, investing in and monitoring new firms in a specific sector and/or on a specific stage of development of a company. As Wright and Robbie (1998) note, "venture capital is particularly appropriate in a specific subset of firms which have non-redeployable or highly specialised assets". Early-stage high technology companies in the Information and Communication Technology (ICT) or biotechnology sectors are typical examples, accounting for roughly two-thirds of all VC investments (BVK, 2003). $\mathrm{VC}$ research has shown that $\mathrm{VC}$-backed firms play an important role in commercialising breakthrough technologies, and has investigated the drivers for value creation in the VC-entrepreneur relationship (Barry et al., 1990; Hellmann and Puri, 2002). Historically, empirical research on venture capital has focussed on ICT and biotech, since these two sectors have the best data availability. Very little work has been done to understand how new sectors for VC investment emerge, which is necessary to understand the development of the sustainable energy VC market.

VC research also provides insights into the venture capital cycle (Gompers and Lerner, 1999). VC is provided to different stages of company development. While seed funding is typically provided by business angels, venture capitalists provide early- and 
expansion stage financing. Venture capitalists will typically look at exiting their investment two to eight years after investing, typically through Initial Public Offerings (IPO) or trade sales. Between expansion stage and IPO, there may be additional financing rounds by Private Equity funds. ${ }^{1}$ For a healthy venture capital market, it is essential that there is sufficient capital and know-how on all stages of the VC cycle, as well as exit opportunities.

\subsection{The investment opportunity in sustainable energy technologies}

The energy sector is one of the largest sectors of the economy, accounting for annual sales of about $\$ 2,000$ billion worldwide (SAM, 2002). The total investment requirement for energy-supply infrastructure worldwide over the period 2001-2030 is estimated at $\$ 16$ trillion by the International Energy Agency, which is a substantial increase, in real terms, compared to the prior 30-year period (IEA, 2003). A set of environmental and security concerns, in conjunction with technological innovation, is currently leading to fundamental changes in the energy industry. More than $80 \%$ of the electricity worldwide is generated based on either fossil fuels, which are one of the main reasons for global warming, or nuclear energy, which involves security concerns and hazardous waste issues. ${ }^{2}$ Looking at all energy (including fuels for transportation and heating), the combined share of oil, coal and gas is $86 \%$ of global energy consumption, with nuclear energy adding another $6.5 \%$ in $2001 .^{3}$ Oil reserves are increasingly concentrated in a few countries of the Middle East, and new strong demand comes from emerging countries like China. Also, more than two-thirds of the primary energy gets lost due to inefficiencies in the energy sector and on the demand side (UNDP/WEC/UNDESA, 2000). Sustainable energy technologies, ${ }^{4}$ such as wind turbines, solar cells, small-scale combined heat and power generation (micro-CHP), or energy efficiency software, can help address the undesirable side effects of energy use. Several governments have started to design policy mechanisms intended to support market introduction of these technologies. At the same time, increasing numbers of both private and corporate energy users are buying green power (Bird et al., 2002).

One particularity of sustainable energy technologies and services is that they create both private and societal benefits. In terms of their private value, they compete directly with conventional energy sources - a wind turbine provides technically more or less the same quality of electricity as a coal-fired power plant. The societal value - avoiding emissions and reducing import dependence - is what makes them attractive for governments. Venture capitalists, unlike governments, look for investments that create private rather than societal value. Looking strictly at private value, the equation often looks unfavourable for sustainable energy technologies today, since they are early on the learning curve and hence they have higher cost. This is only partly offset by side benefits, such as modular scale, lower maintenance, hedging against fuel price fluctuations. So while investment needs are huge in this sector, it is not trivial whether there will be the right incentives to mobilise enough private capital (IEA, 2003). This may be an issue for the venture capital segment of the financial market, too, even though new energy technologies have recently made it to the headlines of the venture capital community. ${ }^{5}$ 


\subsection{Status of VC investment in sustainable energy}

Reliable data about European VC investments in sustainable energy is hard to find, since (a) data on venture capital investment is generally not publicly available, and (b) as energy is an emerging VC category, energy deals are often not properly identified in the statistics. ${ }^{6}$ According to the German Venture Capital Association (BVK, 2003) energy and environmental technologies each accounted for about nine million Euro or $1.3 \%$ of early-stage VC investments in 2002, while biotechnology, and software and communications technologies added up to $63.6 \%$ of all VC investments (see Figure 1). As for global figures, data compiled by Nth Power, a leading energy VC fund based in San Francisco, shows that sustainable energy accounted for $\$ 526$ million or about $2 \%$ of overall VC investments in 2003. Notably, this share has been continuously rising since 2000, with a particular significant increase in Europe.

Figure 1 Sectoral distribution of early-stage VC investments in Germany 2002

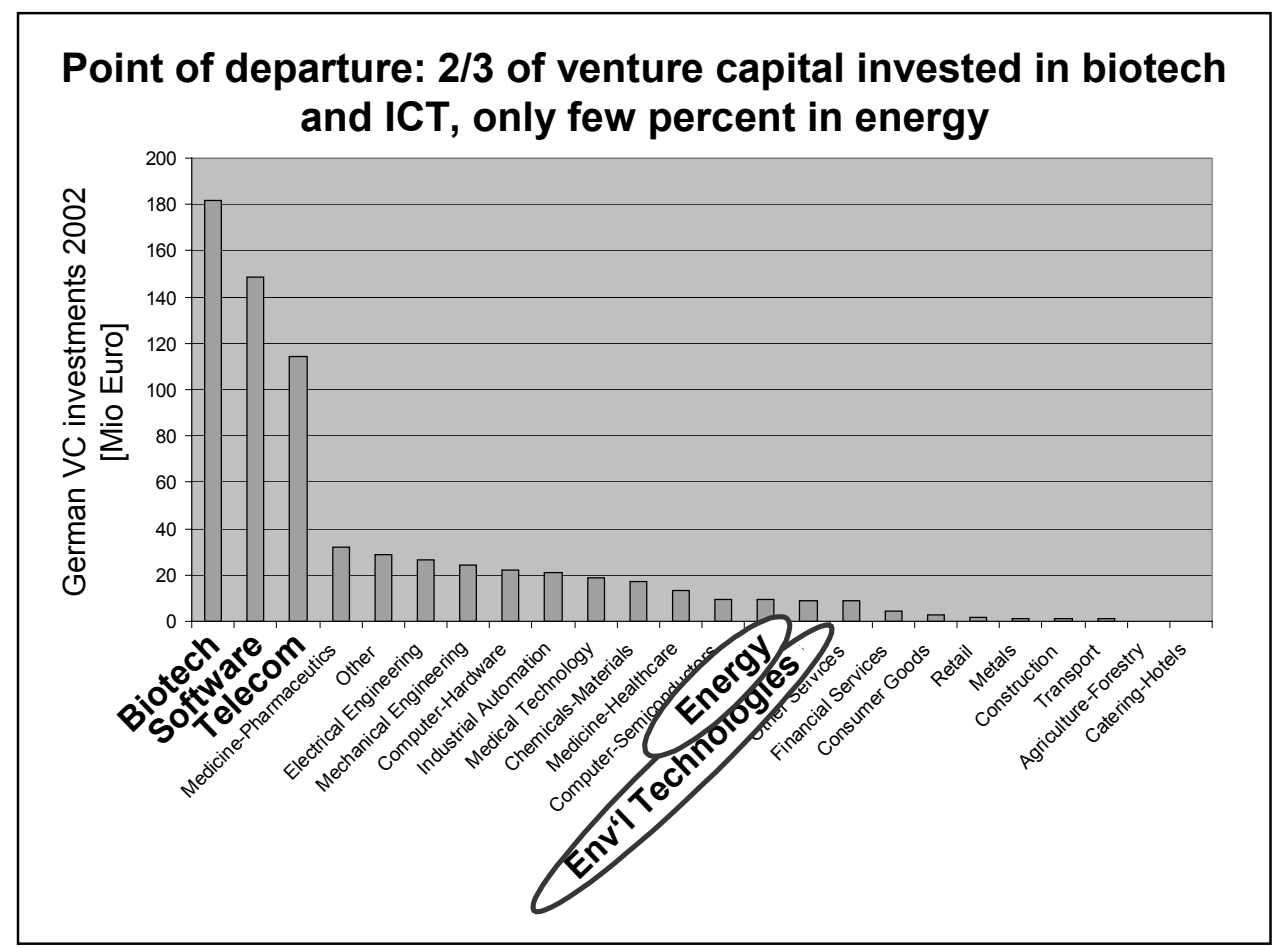

Source: BVK (2003)

Looking at the striking differences in investment between energy technology and VC sectors like biotech and IT leads us to the following two research questions:

1 Which factors determine the attractiveness of sustainable energy as a target for venture capital investments relative to other sectors (like ICT and biotech)?

2 Which drivers and barriers do venture capitalists perceive as influencing future growth of the sustainable energy VC market? 


\subsection{Methodology}

There has been very little industry-specific academic research on venture capital investments in the energy sector to date. Also, the number of funds active in this area and VC-backed energy ventures is still fairly small and their operating history limited to only a few years in most European cases. Therefore, we have chosen a mainly qualitative approach for our research. The core of our data is taken from 23 semi-structured, qualitative, face-to-face interviews with venture capitalists that were performed between August 2003 and March 2004. Interviews usually lasted about 1.5 hours, and were led at the VC fund's premises. Our interviewees were either partners/principals of the VC fund or Senior Investment Managers. We interviewed VCs in nine countries, mainly in Europe, and two interviews in North America. Eleven of these 23 interviews were with independent VCs, 11 with corporate VCs, and one with a government VC. All but one of the VCs in our sample had active investment experience in the energy sector, so we probably had a certain 'believer bias', but also a particularly knowledgeable sample.

To validate our interview data, we also performed a written survey among attendants of the 2nd European Energy Venture Fair in Rüschlikon/Zurich (Switzerland) in October 2003, which is the key industry event for energy venture capitalists in Europe. ${ }^{7}$ The questionnaire asked for barriers to expansion of energy $\mathrm{VC}$, fostering factors for energy VC, exit routes, as well as personal/fund data. The three-page questionnaire was handed out to all 114 participants of the event, of which 64 were venture capitalists, representing 41 different $\mathrm{VC}$ firms. We received 26 responses, of which 23 were from venture capitalists (a-36\% response rate for this group), representing 17 different $\mathrm{VC}$ firms ( $41 \%$ coverage) from 11 different countries, of which nine European. While the sample is small in total numbers, it provides a very good coverage of the energy $\mathrm{VC}$ pioneers in Europe. The quality of the sample is underlined by the experience of the responding VCs. VC professionals in our sample had an average energy industry experience of 8.4 years (ranging from 0 to 42 years), and an average VC industry experience of 4.6 years (between 0 and 15 years). On average, the VC funds that they represented had made 9.8 investments, of which 4.4 in energy. Fifty-six percent of the VCs in our sample represented an independent venture capital fund, 35\% came from corporate venture capital funds, the rest being other investors or consultants.

\section{A 'good industry' for venture capitalists - a matter of risk and return}

Rather than using an existing theory, we performed our interviews with the objective to contribute to theory building in this uncharted territory. In presenting the results of our analysis, we structured them based on the fundamentals of any investment: risk and return. We suggest that VCs, as any investors, will avoid investments where risk is perceived as being too high or returns are expected to be too low to compensate for the risks encountered. This is in line with much of the previous work on VC decision making. ${ }^{8}$ Tyebjee and Bruno (1984) analysed the factors that VCs use in assessing a deal. Starting from 23 characteristics, they reduced those to five underlying dimensions (Market Attractiveness, Product Differentiation, Managerial Capabilities, Environmental Threat Resistance, Cash-Out Potential), which they in turn summarised as describing expected return and perceived risk. Moreover, as Ruhnka and Young (1991) hypothesise, 
VCs with special skills and expertise are able to alter both sides of the return-to-risk ratio for the ventures that they invest in. They can manage risk by possessing particular knowledge about a specific industry, which gives them a competitive advantage over other investors. And they can manage return by leveraging their industry-specific network to increase the probability of a successful exit. Both a VC's expertise and network are typically sector-specific, which explains the existence of $\mathrm{VC}$ funds that specialise in certain industries. We therefore explore the risk characteristics of energy technology VC investments in this section, and subsequently discuss factors that influence their returns (Section 3).

There are many different approaches to defining risk. In the finance literature, risk is usually defined as deviation from an expected result, both upwards and downwards. On the other hand, a popular conception of risk is rather associated with negative deviations, i.e., losses (March and Shapira, 1987). Another distinction is between financial risk and operational (nonfinancial) risk. Operational risk has been defined by Hoffmann (2002) in five categories, namely people risk, relationship risk, technology risk, physical risk, and risk that results from external factors (including regulatory risk).

For venture capital investing specifically, Ruhnka and Young (1991) have compiled a list of 37 different risks that occur on different stages of VC investing. Categorising these risks as either internal or external to the venture, they argue that internal risks dominate for early-stage ventures, while external risks, i.e., those that can be managed by the entrepreneur or the $\mathrm{VC}$ only to a limited extent, increase in relative importance over time as the company matures. Baum and Silverman (2004) choose a different term, when they talk about three types of capital that determine the VC's decision to finance start-up firms in the biotechnology and their impact on future startup performance: Alliance capital, intellectual capital (i.e., patents) and human capital. This can be easily translated into risks, where for example uncertainty about the quality of human capital can be referred to as people risk.

For reasons of practicability, we summarise the risks identified by Ruhnka and Young, and others into five categories: market adoption risk, technology risk, people risk, regulatory risk, and exit risk. For each of these risks, we will answer the following questions:

- Where does this risk come from?

- Why is this risk relevant in a VC investment context?

- How does this risk affect VC investments in energy technology differently than in other sectors?

- How can this risk be managed?

In answering the first two questions, we will mostly draw on VC literature, while the third and fourth questions will mainly be addressed based on data from our interviews.

\subsection{Market adoption risk}

Demand for a new product is usually unknown in advance. The adoption of a new product, service or technology ultimately depends on the customers, and can be influenced by the venture only to some limited extent. An additional source of market adoption risk appears in $\mathrm{B} 2 \mathrm{~B}$ markets with high levels of market concentration, where a small number of potential buyers decide about the adoption of a new technology and act 
as gatekeepers for the venture to reach the final customer. Zider (1998) points out that, in contrast to a common perception, VCs are not particular risk-seekers, but are rather focusing on 'the middle part of the classic industry S-curve', that is the segment in the process of diffusion of innovation where growth rates have already taken off but not yet reached saturation. One way of managing market adoption risk is to avoid early-stage investments, where by definition there is the highest uncertainty about market needs. This can be transferred from individual investments to sectors: in sectors with a certain history of VC investing, such as IT or biotech today, there is less uncertainty about market needs for new technologies than, for example, in distributed energy systems, where it is still unclear who will be promising customer segments and what is the best way of addressing them. Successful market penetration of these technologies, such as fuel cells and other technologies for small-scale combined heat and power generation (micro-CHP), depends on things like that customers must be allowed to connect them to the grid, that interconnection standards exist and that customers are able to sell excess electricity to the grid operator at attractive prices:

\footnotetext{
"A lot of business plans [in the fuel cell sector] rely on other external factors that you cannot control, and a VC is getting very nervous when you see big investment in a capital intensive and regulated market relying on a fundamental change in the environment."
}

On top of these uncertainties with regard to the end user of distributed energy technologies, electric utilities play an important role in market adoption risk since they act as gatekeepers: "One thing certainly that constrains [VC investment in] electricity is that your adoption of a technology still is in the hand largely of utilities".

In the case of sustainable energy technologies, an additional element of market adoption risk is that much of the Unique Selling Proposition (USP) lies in their societal value added, not in the private benefit that they generate for the end user. A mobile phone is likely to be preferred by customers over fixed line telephony because it provides him with completely new (private) benefits. Whether a solar cell will be bought by a residential customer to displace the fixed line electricity in his house is less obvious, since he cannot tell the difference in the final product that comes out of the wall socket. Uncertain advantages from the consumer's point of view have also been identified as one important barrier to sustainable energy investments by European VCs in Kasemir et al. (2000). Rather than seeing this as a higher risk for sustainable energy technologies, one can also look at it as simply being a different risk profile. Positive externalities (such as $\mathrm{CO}_{2}$ emission reductions) associated with these technologies are unique compared to many other sectors that VCs invest in. The challenge lies in getting someone to pay for it, which will be discussed in more detail in the section on regulatory risk below.

\subsection{Technology risk}

VC investments are risky because it is often unknown in advance whether or not a new technology will ultimately work. As Zider (1998) points out, "betting on a technology risk in an unproven market segment is something VCs avoid". He acknowledges, however, that there are exceptions to this rule in the case of 'concept stocks', such as genetic engineering, where technology risk is very high, but potential returns are, too. Technology risk can be managed to some extent by VCs requiring a working prototype before they invest, and by staging investments, so that later financing rounds are tied to 
the achievement of certain milestones in technology development. Technology risk is particularly important when it comes to technologies that are capital intensive to develop and have long lead times. Capital intensity of energy technologies (as opposed to, for example, internet companies) is one of the main barriers mentioned by several VCs:

"[If you develop for example a microturbine with] \$200 million of capital need to go in there, there are very few and almost no deals unless you are in a bold market like in 1999/2000 where you can raise that much money. [...] So in a bold market it works but as soon as the market becomes more normal [...] like now, it's very difficult to find any investors for capital intensive cases like [Capstone]."

One VC in our sample, who is not currently investing in sustainable energy, even saw capital intensity as prohibitive for venture capital investment in the energy sector, and felt like new energy technologies should be financed by other means, such as government funding.

While the challenge of capital intensity is acknowledged by the 'believers' in energy among the VC community, too, they see it as something that needs to be managed rather than an insurmountable barrier. One way of managing capital intensity is to develop adequate business models that allow for maximum impact with limited capital input. Strategies to cope with capital intensity include:

- licensing/manufacturing partnerships

- franchising/distribution partnerships

- $\quad$ early exit

- $\quad$ pursuing multiple target markets (real options).

Implementation of such capital-extensive business models is only beginning to emerge in the energy sector. An example of strategy (a) is Energetech, ${ }^{9}$ a VC-backed Australian wave energy technology venture, which initially intended to go into construction of wave energy plants, but realised that putting their equity money into building concrete walls was too expensive. The company then changed their business model and now focus on the 'intelligent core' of their devices, while contracting the less IP-intensive parts out. Strategy (b) has been adopted by Capstone Turbine, ${ }^{10}$ who initially tried to sell their product directly to every individual commercial customer, but soon had to realise that going through established distributors is more efficient. Strategy (c) is common practice in the biotechnology sector, which is equally capital intensive: "[In] biotech [...] developing, getting a drug from discovery to market is a seven-year process. Although once you get that you have a monopoly in the market [...] for another seven years or so".

In biotech, however, there is an established 'early' exit route for ventures. Biotech VCs manage capital intensity by taking investments only to a certain stage, such as FDA approval for their product, and then exiting through trade sale or IPO. An example of strategy (d) is Enginion, ${ }^{11}$ a German manufacturer of steam cells. The company's primary target market is micro-CHP, i.e., developing units for combined heat and power generation in residential or small commercial buildings. This is a large market, but has a number of entry barriers attached to it. Therefore, the company pursues another near-term market opportunity in parallel, which are Auxiliary Power Units (APUs) for cars and trucks. This provides enginion with two options to capitalise on their heavy R\&D investment, rather than just betting on one horse. 
Finally, capital intensity can actually also be regarded as an advantage rather than a disadvantage, namely for later-stage investors who are looking for larger financing rounds and are not set up to cope with early-stage deals, where they have to put in relatively high management effort to apply relatively small amounts of capital. Apart from some larger VC firms, this might be the rationale behind the oil companies' investment in solar cell manufacturing, which is one of the most capital-intensive renewable energy technologies:

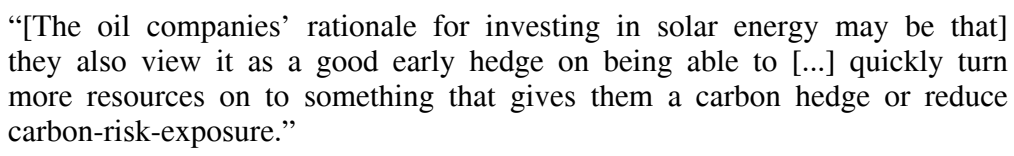

"[The oil companies' rationale for investing in solar energy may be that] they also view it as a good early hedge on being able to [...] quickly turn more resources on to something that gives them a carbon hedge or reduce carbon-risk-exposure."

When we look at technology risk beyond investing in a specific company, but more broadly on a sector level, a question raises about whether there is a sufficient technology base in the energy sector to lead to good VC deals in the first place. One way of measuring this is to look at government $R \& D$ spendings in the energy sector. Margolis and Kammen (1999) argue that there is underinvestment in energy R\&D in the USA. Calculating R\&D intensity, defined as total (public and private) industrial energy R\&D as a proportion of the country's total energy expenditures, they show that the energy sector with just $0.5 \%$ of sales going to $R \& D$ lags far behind sectors like drugs and medicine or communications equipment, who have a R\&D intensity in the order of $10 \%$. Then again, as Sagar and Holdren (2002) argue, measuring R\&D spendings is complicated by the interdisciplinary nature of many energy innovations, so what should count as energy-relevant research is often unclear. In conclusion, there seems to be preliminary evidence that energy suffers from a lack of $R \& D$ that could be an important input to the energy venture capital sector. ${ }^{12}$

\subsection{People risk}

The success of VC investments crucially depends on the ability of entrepreneurs and venture managers to grow the company, or to 'execute' to use a term from typical VC jargon. This can be judged in advance only to a limited extent. High-growth companies constantly change, and that means constant changes in the challenges that their management faces. Apart from careful selection of the investment target and due diligence on the management team, ${ }^{13}$ this risk is typically managed by close monitoring of the investment, coaching the team as the company grows, and sometimes by replacing the existing management. Are there enough creative inventors and courageous entrepreneurs in energy, compared to other sectors? We are faced with different views here. A North American VC seemed not to see a lack of entrepreneurship in energy:

"I don't think that the entrepreneurial instinct or interest drops off a cliff [...] when [...] you get to energy. There are entrepreneurs trying to find opportunities everywhere. [...] They are all driven by greed or wealth creation. But also have these characteristics of being [...] creative-driven and obsessed, good team builders and I don't think that's asymmetric in a sense to the energy sector." 
On the other hand, respondents of our survey, when asked about the importance of 'better engineers for energy ventures' versus 'better management teams for energy ventures' as possible fostering factors for energy $\mathrm{VC}$ in Europe, ranked the issue of better management as the fourth important of 13 items, while better engineers was the least important factor in their view. One possible explanation is that there is a US-European difference here; with Europe having (more than) enough good engineers but not enough business people capable of managing growth for energy ventures. Since successful venture managers need not just creativity and entrepreneurial spirit but also some solid industry expertise, where can they be recruited from? One option is from large companies in the same industry, which is a pattern that can be found in other VC sectors. For energy, this might mean some conflict with the lack of innovativeness in the utility industry discussed above:

\begin{abstract}
"You could find some good people there [in the utility industry]. Provided that they have the right mindset. [...] It's tough. If you stayed there for 25 years, you might be very good, but you're a military and you're not an entrepreneur. They could come from equipment manufacturers. I think the single most important source is equipment manufacturers. [...] But we don't see too many people like that. Because it's by definition risky to do that. Only a small proportion of people want to leave their job in GE or ABB and go to a smaller company."
\end{abstract}

A particular issue in our interviews evolves around the green image that might be associated with sustainable and especially renewable energy technologies. We tried to find out whether VCs perceive this to be reflected in the mindset of entrepreneurs in this sector, and if yes, whether that might lead to a cultural mismatch between these 'green' entrepreneurs and the primarily financially driven venture capitalists. We found some support for this proposition, most pronounced in the following statement by a VC of Italian nationality:

"Enough people in the renewables space, their primary motivation is to save the world, create jobs, equal opportunities, and interestingly enough, many times making a lot of money is almost unethical, you know. And obviously VCs, they shy away from that." (...) "Environmentally oriented people, they see the end of the world coming."

However, asking the question whether this 'save-the-world' image of sustainability entrepreneurs is a major barrier to entry for VCs, we received very mixed responses in our survey, ranging from very strong support to very strong rejection. One way to explain this large variance of answers might be that a major change is going on in the way that sustainable energy is perceived - from an almost esoteric green niche to an established mainstream business:

"Back in 1992 at the time of the [...] Rio Summit, renewables was still an issue of kind of benevolent action, you know, it didn't make economic sense but it was the right thing to do. I think that's increasingly changing. [...] I think it will, you know ultimately the market has to recognise it's a place where people are making money and they'll take it seriously. I think with a lot of literacy they saw the industry at some point as a place where people weren't making money for years and years. [...] [Now] solar is getting to a scale were big investors are starting to pay more and more attention. Same thing with wind. It is, I think, very telling that GE got into that business and then Enron was there too." 


\subsection{Regulatory risk}

The main source of regulatory risk, or political risk, is government regulation of the end market(s) that the venture aims to serve. Political risk scored high among the energy VCs participating in our survey, being the second often-mentioned factor when we asked the 26 respondents an open question about reasons for the lower levels of VC investments in energy compared to other sectors. There was a perception that it is difficult to predict future government subsidies in the energy sector, and that market liberalisation of the electricity sector has somewhat stalled in several countries, making it challenging for new entrants to compete with the former monopolists. Regulatory risk is usually disliked by investors because it seems harder to manage or even outside their area of influence. However, other VC target sectors such as telecom or biotechnology are also highly regulated. VCs in the biotech industry, however, may manage this risk by supporting early-stage R\&D but then exiting their investments prior to achieving regulatory hurdles like FDA approval for new drugs. Regulatory risk can also be managed by careful analysis of the political system, or even actively lobbying for particular forms of regulation. Looking at our interview data, many VCs seemed to share a not-so-enthusiastic picture of governments: "If there is no clear need for the government, make them stay out of the way".

On the other hand, one of the interviewees pointed to another truth below the surface, i.e., below the immediate reflex of VCs against government intervention:

"On a superficial level, VCs will always say that they go out because it [government involvement] is bad for them. You have to push your research a level deeper, because for instance the reason why Quebec has got a $\mathrm{VC}$ industry in life sciences and in IT is because initially there was some heavy-handed governmental intervention. We think it's something like that in the field of energy."

Another VC pointed to lobbying as a form of regulatory risk management: "VCs need to have competence in lobbying if they want to succeed in the energy sector, just like the big American mainstream VCs have their guys in Washington DC".

Finally, a German VC argued that government support for renewable energy in particular can be seen not only as a risk, but also as an opportunity: "We actually think we have a unique opportunity here in Germany with all that government support for renewables. That was one of the reasons for us to invest in a solar cell company".

Government support for VC investments in sustainable energy can take different forms, including policy measures directed at market adoption of sustainable energy technologies (such as energy market liberalisation, removal of coal subsidies, removal of export credit insurance for fossil-based power plants, energy-efficiency standards in the automotive sector, and an EU carbon tax) as well as measures to support VC investment specifically (such as tax incentives for energy efficiency and renewable energy investment, or state guarantees for realised losses in young energy technology companies) (Kasemir et al., 2000). Governments can also directly contribute to the growth of the sustainable energy VC market by investing their own funds. Examples of this include the recent announcement by the largest public pension fund in California, CalPERS, to invest $\$ 200$ million in sustainability or cleantech ventures, as well as government VC funds like Industrifonden in Sweden, which invests part of its capital in sustainable energy ventures. Lerner (1999), in his analysis of the US SBIR programme as 
a government-backed venture capital activity, identifies two rationales for this kind of government intervention in the venture capital sector. First, the social returns from the ventures' $R \& D$ expenditures may exceed their private returns - which should be all the more valid in the case of sustainable energy technologies that help to remove the environmental externalities associated with conventional forms of power generation. Second, awarding public grants might be seen as a form of certification of the firm's quality by knowledgeable government officials, which might address the informational asymmetries that might otherwise have precluded private investments.

\subsection{Exit risk}

The opportunity to exit investments after some years is a key part of the VC cycle, because it allows $\mathrm{VC}$ investors to get a quantitative measure for the VC fund manager's skill, and it allows the $\mathrm{VC}$ to reapply his competencies to a specific part in the life cycle of a company's development where he adds most value (Black and Gilson, 1998). Exits can take five forms (Cumming and MacIntosh, 2003; Gladstone, 1989), of which the first two are most relevant:

1 public offering of the company's shares (IPO)

2 trade sale (or acquisition), where a larger company acquires the shares of the venture

3 secondary sale, where the VC sells its share in the company to a third party like a strategic investor or another $\mathrm{VC}$

4 buyout, where the $\mathrm{VC}$ sells its share to the entrepreneurial firm or its management, and finally, but less desirable

5 write-off in case of the venture's failure.

As Wright and Robbie (1998) point out, most previous research has focussed on IPOs as the exit route (Lange et al., 2001), ${ }^{14}$ while the trade-off between acquisitions and IPOs seems to have been largely overlooked by academic research (Hellmann, 2004). Yet Amit et al. (1998) show for a sample of Canadian VC-backed companies that trade sales are more than twice as common as IPOs. Their explanation is that due to informational asymmetries, strategic acquirers (or the firm's management in the case of a buyout) are in a better position to understand the value of a high-tech venture than an average outside investor. Megginson (2004) points out that exit routes strongly differ between the USA and Europe, with IPOs being the preferred exit route in the USA, but accounting for only $5 \%$ in Europe in 2002, while trade sales and write-offs accounted for $30 \%$ each. One explanation for these differences is that most countries outside the USA lack a similarly well-established stock market for early-stage high technology companies (Black and Gilson, 1998; Kuemmerle, 2001). The relative importance of exit routes also changes over time. During the technology boom in the late 1990s, IPOs were much more likely to occur than in the 2002-2004 time period, when the IPO window was essentially closed in many countries. Among the few authors investigating trade sales as an exit route, Petty et al. (1994) point to the fact that trade sales provide more immediate liquidity, but may not satisfy the objectives of the entrepreneur. Black and Gilson (1998) stress that same point when they argue that exit through IPO provides a unique match of the interests of both the entrepreneur to reacquire control over the company and the $\mathrm{VC}$ to reduce his monitoring cost. 
In stark contrast to the focus on exit through IPO in the (mostly North American) venture capital literature, our survey of energy VCs showed that exit through trade sale is expected to be much more frequent in this sector in Europe. On average, the VCs in our sample expected $80 \%$ of their current portfolio companies to exit through trade sale, and just $20 \%$ through IPO. In terms of possible trade sale buyers for VC-backed energy technology companies, electric utilities seem to be a natural option, given that many European utilities are active in this space with their own Corporate Venture Capital units. However, the electric utility industry does not enjoy a reputation of being overly innovative among the VCs we interviewed:

"In energy, you make money in two ways, either by selling raw services - generation, transmission or distribution - or by arbitraging the price difference between two regions, that's basically trading. So new technologies or innovation don't play a role as a way to engage in continuous growth. So therefore it is in fact tougher to sell to energy companies because they don't have the mindset." - "Pharma companies [...] have to innovate to survive. In three years, $60 \%$ of what you are selling now will be down to $20-25 \%$ on sales. [...] If you don't innovate, if you don't find something new, you're dead. It's simple as that."

Utilities' risk aversion was quoted as another factor that makes them unlikely candidates for $\mathrm{VC}$ exits in the energy technology sector:

"Utilities have a tendency to really only want to work with more mature companies and not with companies that they are concerned would disappear. Whereas you see in companies like, you know, Cisco or maybe even in the Biotech area partnerships between, you know, small lab companies and these big pharmaceutical companies. Utilities don't seem to approach it that way."

Another respondent confirmed that pharma companies have a better understanding of investing in small ventures: "[Big pharma companies act] like a VC, (...) they have a portfolio approach".

Yet another interviewee points out that utilities may not be the only, and in fact perhaps not the most likely trade sale buyers in the energy venture capital sector. Instead, power technology manufacturers constitute an alternative route to market:
"They [power technology manufacturers like GE, ABB] are the ones that ultimately are much more focused on innovation because they know how to absorb it and turn it into a value proposition. There's very little that an electricity company can innovate on, because [...] they are just in the core business of selling, you know, electrons. And there's no big changes that have happened $[. .$.$] since the beginning of last the century that has really changed the$ way that wholesale power has been delivered to costumers."

This view was confirmed by a majority of participants in our survey, who saw power technology manufacturers such as GE, Siemens, and ABB as the most likely trade sale buyers for energy technology ventures, clearly more important than electric utilities and oil companies. Whether the expectations of the VCs vis-à-vis power technology manufacturers will be met in reality remains to be seen. At the time of our survey, GE was the only one of these companies that had made a handful of significant acquisitions in the sustainable energy sector, buying the wind turbine manufacturing business from Enron, the Austrian biogas and CHP specialist Jenbacher, and the assets of Astropower, the US solar cell manufacturer. Notably, none of these three deals was a case of successful exit for a VC. Both Enron and Astropower had gone bankrupt at the time that GE made the acquisitions, and Jenbacher was a publicly traded company. Siemens has 
entered the sustainable energy sector two years later than GE with the acquisition of Bonus, the privately held Danish wind turbine manufacturer, in late 2004. One of the few examples of a successful trade sale for a European energy VC so far was FKI's acquisition of DeWind, the German wind turbine manufacturer, from MVV's corporate venture capital fund. Understanding the likelihood of these companies to actually acquire VC-backed energy technology start-ups in the future will be an important determinator of the sector's ability to attract venture capital.

Finally, going back to our research question about the relevance of each of the risks we discussed in this section for the future growth of $\mathrm{VC}$ investments in the energy sector, exits have an important function in that they draw other investors' attention to the opportunities in energy venture capital. With that regard, the energy VCs we interviewed appeared to be fairly sceptical about the sector that they invested in: "There aren't that many success stories, [and] the few success stories that there were three years ago [...] created a huge bubble in the energy sector".

The perception of 'few success stories' expressed here is shared by participants in our survey. Of the 26 responding European energy VCs, only nine could answer our question about the most successful exit for an energy VC in the past decade. A total of seven different companies were named, one of which was not an energy company. In another case, there actually was no exit because the planned IPO of the company had failed, and yet another case described a company without VC-backing. Of the remaining four truly successful energy VC exits named by our survey respondents, three companies were located in North America (Plug Power, Capstone and Ballard) and can justifiably be attributed to the energy technology bubble in 1999 and 2000. The only European company that was mentioned was Vestas Wind Systems of Denmark. It comes as no surprise then that 'success stories of VCs exiting energy investments' was the top scorer in our survey when we asked respondents to judge the importance of each of 13 fostering factors that could accelerate growth of sustainable energy VC investments over the next five years. This leads us to take a closer look at the other side of the risk-return equation in the following chapter.

\section{Return}

From a venture capitalist's perspective, a return on investment is realised at the time of exit. We will briefly discuss the variables determining VC returns (Section 3.1) with regards to the relative attractiveness of sustainable energy as a target for VC investments, as well as barriers and fostering factors for further growth. Subsequently, we take a look at actual VC returns in the energy sector (Section 3.2).

\subsection{Factors influencing energy VC returns}

On the level of an individual portfolio investment, $\mathrm{VC}$ returns are basically a product of three variables:

1 the price the VC paid at the time of investing

2 the sales price at the time of exiting the investment by selling shares on the public market or to a trade sale buyer

3 the time between one and two, i.e., between investment and exit. 
Obviously, the best return will be achieved by buying low, selling high, and doing so quickly.

The first part of the equation, the purchasing price for energy VC investors, depends on a number of factors, including supply and demand for energy $\mathrm{VC}$ deals, and the reputation of the VC (Black and Gilson, 1998). All things being equal, more supply (i.e., entrepreneurial firms seeking funding) should lead to lower prices, because VCs can choose from a larger variety of investment opportunities, and increasing demand (i.e., VCs looking for investment opportunities) should lead to higher prices (Gompers and Lerner, 2000). Anecdotal evidence from the energy technology industry does not seem to support any substantial supply-demand imbalances compared to other VC sectors. On the supply side, specialist energy VCs report a ratio of deal flow to actual investments in the order of magnitude of 100:1, which is comparable to standard VC ratios. On the demand side, recent articles from industry journals indicate increasing excitement among some of the mainstream VCs about opportunities in the energy sector, which should lead to better prices for the entrepreneurial ventures, hence somewhat diminishing the prospects for good VC returns. However, this seems to be far from a hype that would see many VCs compete for energy deals and driving up prices. Anecdotal European evidence suggests that, even in cases where deals have reached substantial publicity, the number of knowledgeable VCs truly interested in investing seems to match with, but not greatly exceed the financing needs of the venture. The reputation of the $\mathrm{VC}$ might have an effect on its negotiating power, hence resulting in a cheaper price for the investment. Some specialist VCs in the energy sector have indeed managed to build up a good reputation for their industry expertise, but this should not have an impact on the sector as a whole, but rather give those VCs a competitive advantage over some of their peers, just as other sectors have seen a tier of top-quartile VC funds persistently outperform their peers (Kaplan and Schoar, 2004).

The second part of the equation, the price at exit, looks differently at the exit routes discussed above. For IPOs, the VC's return depends to some extent on the IPO price, but venture capitalists, as well as other insiders such as the entrepreneur, usually have to agree to a 180-day post-IPO lock-up period during which they are not allowed to sell their shares. Even then, VC investors cannot immediately sell all of their shares without having a serious impact on the company's share price performance. This is particularly true for early-stage technology companies, where the liquidity of the stock may be low. Therefore, divestment typically occurs in multiple stages, and total holding periods can be as long as 1-3 years after the IPO. ${ }^{15}$ Obviously, share price performance post-IPO depends on various factors, including company news but also overall market trends that cannot be managed by the VC. The typical fluctuations in stock markets also mean that returns that can be realised through this exit route will be highly cyclical in nature, with VCs making better returns when the particular sector is in favour of the market, and vice versa.

In the case of exit through trade sale, the price and therefore the return to the VC depend not only on the fundamental value of the venture, but also on its strategic value to the acquirer. For example, a gas turbine manufacturer may be prepared to pay a premium for acquiring a fuel cell venture if he sees this as a potential threat to its incumbent business. As a tendency, more competition on the level of potential acquirers should drive this premium up, while it should be lower in monopolistic or oligopolistic markets. Looking at the energy sector, the European market has oligopolistic characteristics both 
on the level of electric utilities, as potential users of sustainable energy technologies, as well as on the level of power technology manufacturers. This might negatively impact the price that can be achieved in trade sales. Further research can test this empirically by comparing trade sale performance of VC deals across different sectors, combined with an analysis of the level of market concentration among the trade sale buyers in these sectors.

The third and final part of the $\mathrm{VC}$ return equation, the time between investment and exit, is important because even if VCs neither pay higher prices for investing in energy deals, nor achieve less favourable terms when exiting their investment, the annualised return may still be worse than in other sectors when the investment cycle is significantly longer. This leads back to the issues of capital intensity and long technology lead times discussed in the section on technology risk above (Section 2.2), and will therefore not be discussed in further detail here. An empirical investigation of average holding periods for energy VC investments compared to biotech or ICT investments would shed more light on this issue, but will be challenging to do at this point given the short history of energy $\mathrm{VC}$ investments in Europe.

\subsection{Early empirical evidence on past energy VC returns}

A simple and common form for investors to estimate expected returns from venture capital investment in a certain sector is to look at IPO performance of previous venture-backed firms. In the energy technology sector, this provides a not too promising picture at first sight. Figure 2 gives four examples of US-based, VC-backed energy technology companies: Evergreen Solar, a solar cell manufacturer, Beacon Power and Active Power, both developers of energy storage technology (flywheels), and Plug Power, a fuel cell company. All of these were backed by some of the most prominent US energy venture capital firms prior to their Initial Public Offerings (IPO) in 1999 and 2000 and traded between 63 and 95\% below their IPO price on 3 September 2004.

Figure 2 Post-IPO price performance of VC-backed energy technology companies versus NASDAQ index

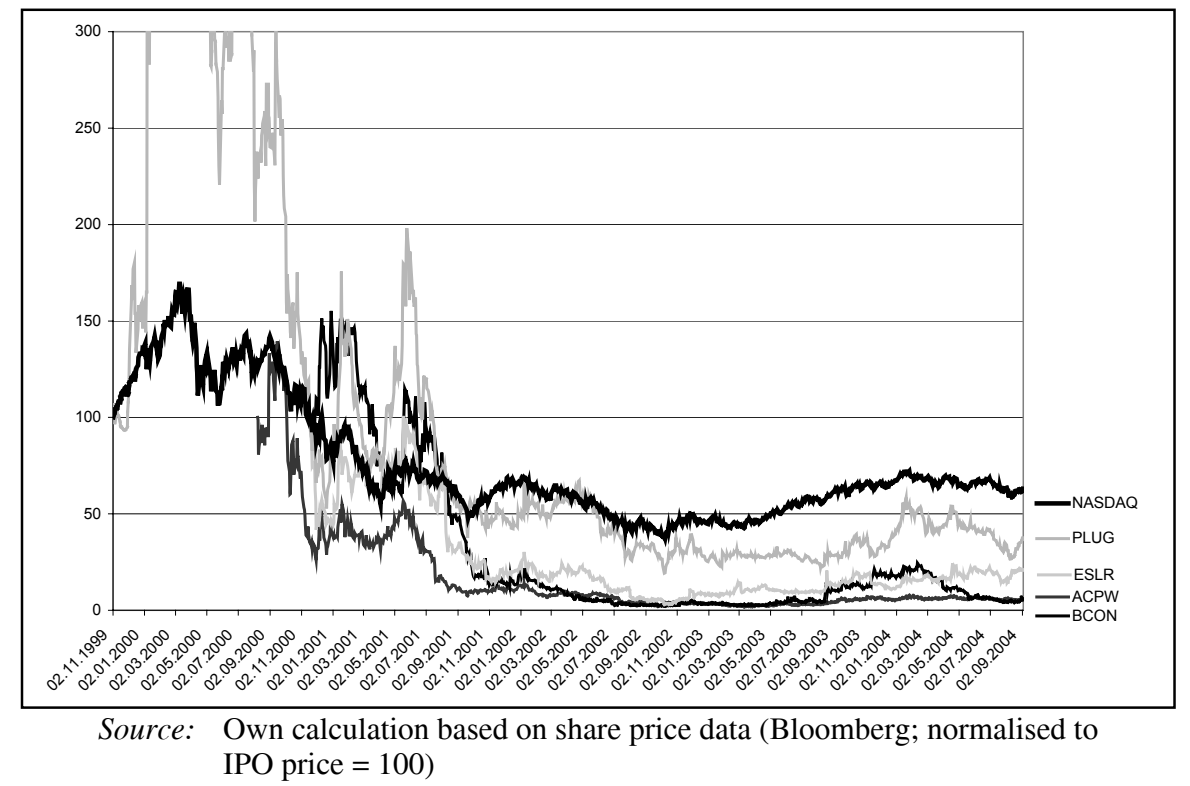


Then again, looking at the stock price performance post-IPO does not tell the full story. VCs typically invest well before the IPO event, and at lower prices than the IPO price. Also, they are usually free to divest the stock after the lock-up period expired, so even if the long-term performance of these shares looks less than promising, a VC investor who divests at the right time may realise a decent return. Measuring actual energy VC returns is complicated by the fact that the exact timing of the divestment is not publicly available information. To get a clearer picture of at least the theoretical returns that a VC investor could have realised had he sold his shares at the first day after the end of the lock-up period, we calculated the annualised Internal Rate of Return (IRR) ${ }^{16}$ for VC investors in the four companies mentioned above. We gathered data about the purchasing price that investors paid for the company's shares in various pre-IPO financing rounds from the companies' IPO prospectuses. On the other side of the equation, we determined the share price at 180 days after the IPO, the end of the lock-up period for VC investors. ${ }^{17} \mathrm{We}$ then annualised these returns by taking into account the time between the various financing rounds and the end of the lock-up period. The results for the four energy technology companies are shown in Figure 3, providing quite a different picture: The lowest IRR in the 15 financing rounds that we looked at was $49 \%$ p.a. for investors in Evergreen Solar's early stage (Series B) financing, which is still well in the range of typical VC return requirements of $30 \%-50 \%$ p.a. All other rounds exceeded this, with investors in Plug Power's pre-IPO (Series E) financing round making a comfortable 5231\% IRR. We have to acknowledge that the Plug Power case may be exceptional because the end of the lock-up period in late April 2000 coincided with the peak of the technology bubble and also benefited from a fuel cell hype at the time. Another indicator for the influence of the bubble is that returns for these four companies increase over the subsequent financing rounds of each company. One would expect exactly the opposite: early-stage investors usually have higher hurdle rates due to the higher risk they incur, while IRR should decrease for later stage financing rounds.

Figure 3 Theoretical VC returns for selected energy technology companies

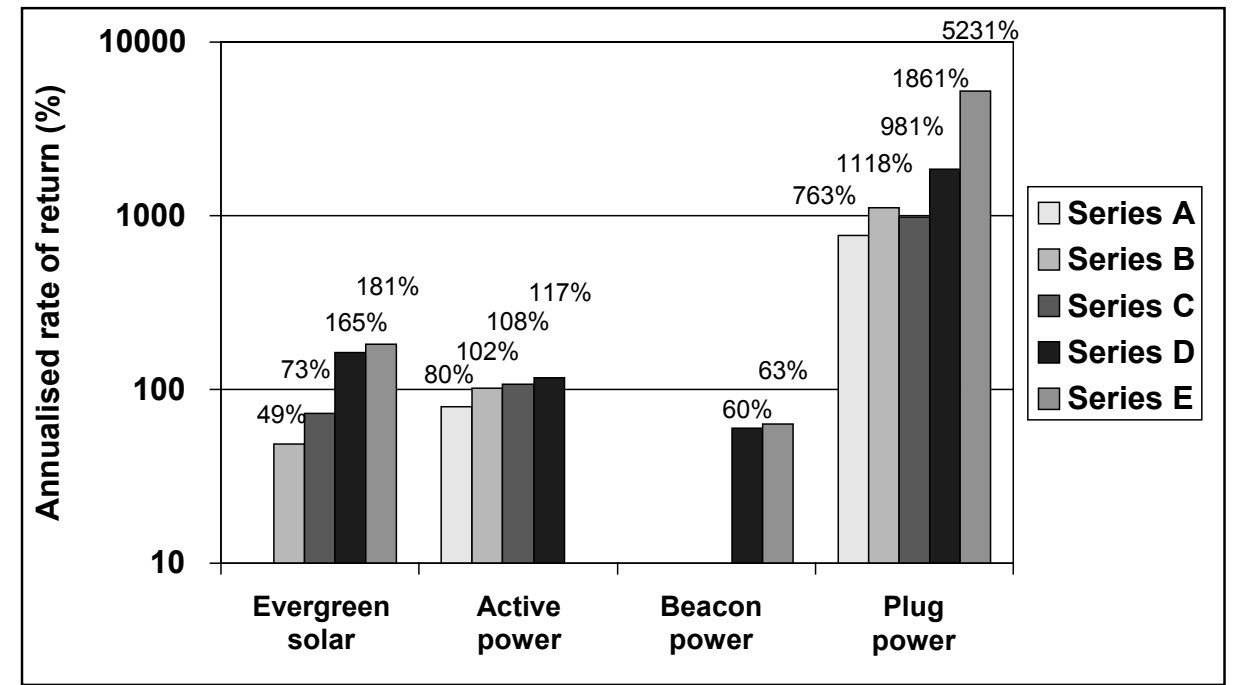

Source: Own calculation based on VC investment data from IPO prospectuses and share price data (Bloomberg) 
We acknowledge some limitations of this analysis. First, the sample of just four companies that we looked at here for reasons of convenient data availability needs to be expanded in a broader analysis, particularly with regard to non-US companies. Second, any analysis of VC returns that looks at successful IPOs is inherently subject to a survivorship bias, even if this is to some extent already considered in the VCs' return requirements that account for the risk of failure in some of their portfolio companies. Third, trade sales need to be added to get a full picture of exiting energy VC investments, even if data is harder to find than in the case of IPOs. Ultimately, energy VC returns will be more accurately measured by looking at overall fund returns (Kaplan and Schoar, 2004; Gompers and Lerner, 1998; Jones and Rhodes-Kropf, 2003; Ljungqvist and Richardson, 2002). This, however, can only accurately be done after a fund has been liquidated. Therefore, such an analysis is subject to a time lag of about a decade after energy technology VC funds are first set up, which makes it difficult to apply to the emerging European energy VC sector before the 2010 timeframe.

Nevertheless, we can conclude that there is at least anecdotal evidence for attractive returns by venture capitalists in the energy sector. ${ }^{18}$ Our exploratory analysis shows that a common perception - even among the energy VCs that we interviewed - of energy as a conservative sector where high-tech investors are unable to make money needs to be revisited, at least for the period in 2000 and 2001 where public financial markets provided a favourable environment for energy technology stocks. This means that rational risk-return considerations can apparently only explain part of the story when we ask for reasons that determine the lower level of $\mathrm{VC}$ investments in energy compared to some of the other industries. In Section 4 below, we therefore turn to factors that are beyond the immediate rationality of risk and return.

\section{The time factor: path dependencies in $\mathrm{VC}$ investing}

The previous sections have highlighted some of the differences in perceived risk and expected return that can help explain how venture capitalists consider the attractiveness of sustainable energy technologies compared to other sectors. However, there is not sufficient evidence to support the order-of-magnitude difference observed in VC investment levels, and hence answer our research question. Instead, there is an underlying theme both in our interview data as well as in VC literature that can be more clearly understood in an evolutionary perspective: The time it takes for the venture capital market to adapt to changing opportunities, and the inherent path dependencies. ${ }^{19} \mathrm{~A}$ process is path dependent if what has happened in the past has an impact on the choices that are available in the present. Path dependencies in venture capital can be identified on the supply and the demand-side of the market.

In terms of venture capital supply, Gompers and Lerner (1999) point out that, unlike most financial markets, the VC industry adjusts very slowly to shifts in the supply of capital or the demand for financing. They argue that this is due to the nature of the companies that they invest in, which usually require long-run illiquid investments. VCs need to secure funds from their investors for periods of a decade or more, and consequently the supply of venture capital cannot adjust as quickly as for example mutual or hedge funds. Another factor that is difficult to adjust according to Gompers and Lerner is the supply of venture capitalists, since it is difficult and time-consuming to acquire the skills needed for successful VC investing. Also, raising new funds without a track record 
is a challenging task, which inherently slows down adjustment of VC investment levels to changes in investment opportunities. Black and Gilson (1998), in their attempt to explain differences in the development of VC markets between the USA and other countries, concur that experienced VCs as well as investment bankers experienced in taking early-stage companies public are critical institutions that will not develop quickly. They conclude that a 'strong venture capital market thus reflects an equilibrium of a number of interdependent factors, only one of which is the presence of a stock market'.

Some of these 'interdependent factors' are aspects of path dependencies on the demand side of the venture capital market. Kuemmerle (2001; Black and Gilson, 1998), in his comparison of the evolution of VC industries in the USA, Germany and Japan, points out that "an active venture capital industry is argueably more difficult to create than an active buy-out industry because the former typically requires not just a functioning financial system, but also a fertile technology system and a climate conducive to entrepreneurship". As much as these authors addressed issues that were important for answering our research question, it should be noted that the statements quoted here are usually qualitative side notes in the VC literature, but have hardly been put to the forefront of rigorous academic analysis. Questions about the process of adjusting demand and supply in the VC market and changing sector allocation seem to be a gap in previous research. Addressing this gap in future research is important in order to understand how new market sectors for VC investment emerge.

We can provide some early evidence from our interviews about the points raised here. One example of path dependencies on the supply side that we encountered is the fact that VCs tend to invest in areas where they feel competent, and this in turn is a function of their previous experience - in other words: money flows where money knows. As one of our interviewees, partner of a VC fund with focus on IT and biotech, has put it:

\begin{abstract}
"I think [...] there is one reason [for the low level of energy $\mathrm{VC}$ investment] which has to do with the capabilities of people and funds. People tend to invest in technologies that they know, where they know people they can talk to, where they can check the technology is good, is different compared to where the market is, to other things on the market. And most of the funds have people that come either from three sectors, IT, telecom, or life sciences." - "Look at [my colleague] here, coming from a very successful IT company, founded by probably Canada's four most successful entrepreneurs. You know, he has a network, has people he can call and check. He knows people telling him something about wireless, people he can talk to. And I can call people in biotech, and suddenly have an answer. Many funds don't have those networks [in energy], so when they hit an energy deal they don't want to do it because you have so much work to do when you have a deal and it's difficult to find the expertise, and they just put it away and never answer to it. And it just dies because people don't get it and that's probably certainly one key reason - the lack of people in funds who have a network in the energy sector."
\end{abstract}

Then again, the conventional wisdom of VCs is that they are not just routinely doing what they have always done, but that they are if not geniuses, than at least visionaries to some extent and as such by definition immune against path dependencies. According to one of our interviewees, however, this picture may be the exception rather than the rule in the energy sector: 
"The other [issue] is, are VCs competent enough to see, to think in a contrarian fashion and see the opportunities that aren't obvious in the market today? Because that's ultimately where VCs, where the really good venture capitalists make their money, because they are investing their time where nobody sees it coming. And that may be just an issue of there aren't enough practitioners in the energy area. How many, you know, really creative revolutionary thinkers are out there investing in energy and really see where this industry is transforming and changing. There aren't that many and there aren't that many that have funds behind them. Right!?"

As a conclusion, growing the energy VC market would mean that the amount of visionaries in the energy VC community needs to increase, which might be a challenging or time-intensive endeavour. As one interviewee puts it, alluding to the inevitable trial-and-error process that marks the way towards making competent investment decisions in a new sector: "It takes ten million dollars to educate a VC".

Perhaps somewhat typical of an evolutionary perspective, the question remains whether anything can be done about these issues, or whether the result of the analysis is simply to increase the reader's patience, because we know now that these things need time to be resolved, but are ultimately going to happen. ${ }^{20}$ Taking the apparent lack of visionaries as an example: Can government or any other invisible hand direct more visionaries to the energy $\mathrm{VC}$ sector? Maybe not. A more realistic view seems to lead us back to our risk/return considerations: demonstrating that there are opportunities to make good returns, and understanding how to manage the risks will probably be a particularly promising way to increase energy $\mathrm{VC}$ investment levels. Also, further research that improves our understanding of drivers behind the shifts in VC supply and demand might help to bring the process closer to a speed that would be desirable from a societal point of view, or simply rational from a pure risk/return perspective. Such research can address three levels:

1 supply of capital

2 supply of venture capital professionals

3 demand for venture capital.

On the capital supply side, research should be directed at investors in VC funds (pension funds, financial investors, and strategic investors), aiming at understanding how they perceive opportunities in the energy sector and how this translates into their sector allocation within the $\mathrm{VC}$ asset class. On the $\mathrm{VC}$ level, tracking the background of energy VC professionals might be a first step to improve our understanding of where the required competence for $\mathrm{VC}$ investments in energy has come from so far, and where more of it may come from in the future. Finally, on the demand side, research should compare the energy innovation system with the innovation system in biotechnology and IT, for example taking Kuemmerle's (2001; Black and Gilson, 1998) question of whether there is a climate conducive to entrepreneurship from a country level to an industry level. 


\section{Concluding remarks}

We started this paper by asking the question "Do venture capitalists really invest in good industries?" We addressed this question by looking at the risk-return characteristics of VC investment opportunities in the energy sector to see whether energy lacked some of the 'good industry' characteristics that would attract more venture capital. Based on our analysis, the answer is: "yes, to some extent". In fact, discussing the risk and return of VC investing in sustainable energy technologies compared to other sectors, we have identified a number of relevant sector-specific risks (see summary in Table 1). In terms of market adoption risk, the conservatism of the electric utility industry is perceived as slowing down adoption of innovative technologies. Another factor is the partly societal nature of the benefits created by sustainable technologies. Technology risk is high compared to typical information technology deals (due to capital intensity and long technology lead times), but not fundamentally different from many biotechnology deals. People risk seems to be an issue with regard to a perceived (yet not undisputed) lack of qualified energy management teams (rather than engineers), especially in Europe. Unlike some of the more developed sectors for $\mathrm{VC}$ investing, there are few serial entrepreneurs in energy so far. Also, some VCs perceive the 'green' image of sustainable energy and entrepreneurs in this sector as increasing people risk. Regulatory risk seems to be particularly relevant in the energy sector, and few VCs seem to believe that the regulatory opportunities created by climate and renewable energy policies compensate for that. Finally, exit risk is an important factor. The number of success stories in terms of energy IPOs is limited so far. As for trade sales as the expected dominant exit route, the industry's most visible companies, electric utilities, are not perceived as likely candidates for acquiring VC-backed entrepreneurial energy firms. Instead, they are portrayed as being more conservative than their counterparts in pharma/biotech or IT.

Table 1 Sector-specific risks for energy VC investments and ways of managing them

\begin{tabular}{|c|c|c|}
\hline Category of risk & Perceived problem & Potential solution \\
\hline Product market risk & $\begin{array}{l}\text { Conservative utilities as customers } \\
\text { Societal vs. private benefits }\end{array}$ & $\begin{array}{l}\text { Addressing more than one } \\
\text { market segment } \\
\text { Identify clear customer value }\end{array}$ \\
\hline Technology risk & $\begin{array}{l}\text { Long lead times } \\
\text { Capital intensity } \\
\text { Infrastructure }\end{array}$ & Appropriate business model \\
\hline People risk & $\begin{array}{l}\text { Few serial entrepreneurs } \\
\text { Good engineers, poor managers? } \\
\text { 'Green' image }\end{array}$ & $\begin{array}{l}\text { Time } \\
\text { Market liberalisation increases } \\
\text { human mobility }\end{array}$ \\
\hline Regulatory risk & $\begin{array}{l}\text { Energy policy framework seems } \\
\text { unpredictable }\end{array}$ & $\begin{array}{l}\text { Increase understanding } \\
\text { Lobbying } \\
\text { Diversification }\end{array}$ \\
\hline Exit risk & $\begin{array}{l}\text { Few success stories (IPOs) } \\
\text { Utilities unlikely candidates for } \\
\text { trade sales }\end{array}$ & $\begin{array}{l}\text { AIM } \\
\text { Power technology manufacturers as } \\
\text { potential trade sale buyers }\end{array}$ \\
\hline
\end{tabular}


Yet, we do not find unlimited support for the hypothesis that energy is a 'bad industry' for venture capitalists, and hence that $\mathrm{VC}$ investment allocation across industries would follow a fully rational pattern. In discussing the risks identified, we pointed to ways of managing each of them. Product market risk and technology risk can basically be addressed by appropriate business models, putting an emphasis on clear customer value and efficient use of capital. People risk seems to be largely a matter of time, where in a more mature market, more experienced entrepreneurs will develop. The opportunities created by market liberalisation may also increase the availability of good managers for innovative energy ventures. In terms of regulatory risk, some of the VCs' perceptions seem to be based on the lack of understanding of the energy policy framework. Furthermore, incumbent industries have developed ways of managing regulatory risk, such as lobbying or geographical diversification. Successful VCs may adopt some of these practises. Finally, our analysis of exits showed that there is at least anecdotal evidence for success stories, despite the fact that few of the VCs in our sample were able to name successful previous exits in the sector. Also, the recent series of energy technology IPOs at London Stock Exchange's Alternative Investment Market (AIM), which included several international companies, illustrates some of the less obvious exit opportunities. As for trade sales, our analysis clearly showed that power technology manufacturers rather than utilities are likely candidates for trade sales.

In conclusion, both on the risk and on the return sides of the equation, the gradual differences between energy and the other VC sectors alone seem to be insufficient to fully explain the difference observed in VC investment levels, and a more comprehensive answer will have to take an evolutionary perspective. This will not help to find a definitive answer to the question whether VCs invest in good industries, but instead will shed light on a slightly different question, which is: "Why does it take so long for VCs to invest in newly emerging 'good' industries, and what can be done about it?" Overcoming inherent path dependencies will be an important challenge for entrepreneurs, financiers and policy makers who have an interest in seeing the market for sustainable energy $\mathrm{VC}$ grow. At the same time, those who are successful at it more quickly than others are likely to benefit greatly from the fundamental changes in the energy sector.

\section{Acknowledgements}

Wüstenhagen acknowledges valuable feedback from participants of the oikos $\mathrm{PhD}$ Summer Academy 2004 'Creating and Transforming Markets for Sustainability', particularly Sanjay Sharma, and of the Academy of Management/EABIS Professional Development Workshop at Fontainebleau (France) in October 2004, particularly Mike Russo and Kai Hockerts. Teppo acknowledges financial support from TEKES. Both authors are grateful to Bill Moore for comments on prior drafts of this paper and for providing valuable data inputs for the discussion on VC returns and IPO performance. An earlier version of this paper titled 'Venture capital investment in sustainable energy: factors determining the emergence of a new market' has been presented at the GRONEN Research Workshop 2004, in Granada, Spain, on 22-23 April 2004, and at the International Conference 'Innovation, Sustainability and Policy' of the riw Network, on 23-25 May 2004, in Kloster Seeon, Germany, and a more extended review draft was made available to European VCs as a discussion paper of the Institute for Economy and the Environment at the University of St. Gallen in October 2004. 


\section{References}

Amit, R., Brander, J. and Zott, C. (1998) 'Why do venture capital firms exist? Theory and Canadian evidence', Journal of Business Venturing, Vol. 13, No. 6, pp.441-467.

Barry, C.B., Muscarella, C.J., Peavy, III, J.W. and Vetsuypens, M.R. (1990) 'The role of venture capital in the creation of public companies: evidence from the going-public process', Journal of Financial Economics, Vol. 27, No. 2, pp.447-472.

Baum, J.A.C. and Silverman, B.S. (2004) 'Picking winners or building them? Alliance, intellectual, and human capital as selection criteria in venture financing and performance of biotechnology startups', Journal of Business Venturing, Vol. 19, pp.411-436.

Bird, L., Wüstenhagen, R. and Aabakken, J. (2002) 'A review of international green power markets: recent experience, trends, and market drivers', Renewable and Sustainable Energy Reviews, Vol. 6, No. 6, pp.513-536.

Black, B.S. and Gilson, R.J. (1998) 'Venture capital and the structure of capital markets: banks versus stock markets', Journal of Financial Economics, Vol. 47, pp.243-277.

Bundesverband Deutscher Kapitalbeteiligungsgesellschaften (BVK) (2003) Jahresstatistik 2002 des Bundesverbandes Deutscher Kapitalbeteiligungsgesellschaften - German Venture Capital Association e.V., Berlin.

Cumming, D.J. and MacIntosh, J.G. (2003) 'A cross-country comparison of full and partial venture capital exits', Journal of Banking and Finance, Vol. 27, No. 3, pp.511-548.

Fried, V.H. and Hisrich, R.D. (1994) 'Toward a model of venture capital investment decision making', Financial Management, Vol. 23, No. 3, pp.28-37.

Gladstone, D. (1989) Venture Capital Investing, Englewood Cliffs, NJ: Prentice Hall.

Goldstone, J.A. (1998) 'Initial conditions, general laws, path dependence, and explanation in historical sociology', American Journal of Sociology, Vol. 104, No. 3, pp.829-845.

Gompers, P. and Lerner, J. (1998) 'What drives venture capital fundraising?', Brookings Papers on Economic Activity and Microeconomics, July, pp.149-192.

Gompers, P. and Lerner, J. (1999) The Venture Capital Cycle, Cambridge MA: MIT Press.

Gompers, P. and Lerner, J. (2000) 'Money chasing deals? The impact of fund inflows on private equity valuation', Journal of Financial Economics, Vol. 55, pp.281-325.

Hellmann, T. (2004) 'IPOs, acquisitions and the use of convertible securities in venture capital', Working Paper, Stanford Graduate School of Business, January, No. 1702, http://strategy.sauder.ubc.ca/hellmann/pdfs/xit04.pdf.

Hellmann, T. and Puri, M. (2002) 'Venture capital and the professionalization of start-up firms', Journal of Finance, Vol. 57, pp.169-197.

Henig, P. (2003) 'Bright idea', Venture Capital Journal, November, pp.32-38.

Hoffman, D.G. (2002) Managing Operational Risk: 20 Firmwide Best Practice Strategies, Chichester: John Wiley and Sons.

International Energy Agency (IEA) (2003) World Energy Investment Outlook, Paris.

Jones, C. and Rhodes-Kropf, M. (2003) 'The price of diverifyable risk in venture capital and private equity', Working Paper, Columbia University.

Kaplan, S. and Schoar, A. (2004) 'Private equity performance: returns, persistence and capital flows', Journal of Finance, forthcoming, http://gsbwww.uchicago.edu/fac/steven.kaplan/ research/pereturns.pdf.

Kasemir, B., Toth, F. and Masing, V. (2000) 'Climate policy, venture capital, and European integration', Journal of Common Market Studies, Vol. 38, No. 5, pp.891-903.

Kuemmerle, W. (2001) 'Comparing catalysts of change: evolution and institutional differences in the venture capital industries in the US, Japan and Germany', in H. Chesbrough and R.A. Burgelman (Eds.) Comparative Studies of Technological Evolution, Elsevier, Vol. 7, pp.227-261. 
Lange, J.E., Bygrave, W., Nishimoto, S., Roedel, J. and Stock, W. (2001) 'Smart money? The impact of having top venture capital investors and underwriters backing a venture', Venture Capital, Vol. 3, No. 4, pp.309-326.

Lerner, J. (1999) 'The government as venture capitalist: the long-run impact of the SBIR program', The Journal of Business, Vol. 72, No. 3, pp.285-318.

Ljungqvist, A.P. and Richardson, M.P. (2002) 'The cash flow, return and risk characteristics of private equity', Working Paper, New York University.

Logerfo, J. (2005) Cleantech Venture Investing: Patterns and Performance, in N. Parker and D. Proper de Callejon (Eds.) www.cleantech.com.

Manigart, S. (1994) 'The founding rate of venture capital firms in three European countries (1970-1990)', Journal of Business Venturing, Vol. 9, pp.525-541.

March, J.G. and Shapira, Z. (1987) 'Managerial perspectives on risk and risk taking', Management Science, Vol. 33, No. 11, pp.1404-1418.

Margolis, R.M. and Kammen, D.M. (1999) 'Evidence of under-investment in energy R\&D in the United States and the impact of federal policy', Energy Policy, Vol. 27, pp.575-584.

Megginson, W.L. (2004) 'Toward a global model of venture capital?', Journal of Applied Corporate Finance, Vol. 16, No. 1, pp.8-26.

Moore, B. (2005) 'Energy technology initial public offerings: characteristics, costs, performance, and venture capital implications', PhD Thesis, University of St. Gallen, forthcoming.

Müller, C. Fujiwara, T. and Herstatt, C. (2004) 'Source of bioentrepreneurship: the cases of Germany and Japan', Journal of Small Business Management, Vol. 42, No. 1, pp.93-101.

North, D.C. (1990) Institutions, Institutional Change and Economic Performance, Cambridge University Press.

Petty, J., Bygrave, W. and Shulman, J. (1994) 'Harvesting the entrepreneurial venture: a time for creating value', Journal of Applied Corporate Finance, Vol. 7, pp.48-58.

Pierson, P. (2000) 'Increasing returns, path dependence, and the study of politics', American Political Science Review, Vol. 94, No. 2, pp.251-267.

Ruhnka, J.C. and Young, J.E. (1991) 'Some hypotheses about risk in venture capital investing', Journal of Business Venturing, Vol. 6, pp.115-133.

Sagar, A.D. and Holdren, J.P. (2002) 'Assessing the global energy innovation system: some key issues’, Energy Policy, Vol. 30, pp.465-469.

Sustainable Asset Management (SAM) (2002) Changing Climate in the Energy Sector - A New Wave of Sustainable Investment Opportunities Emerges, 2nd edition, Zollikon/Zurich, June, www.sam-group.com.

Tyebjee, T.T. and Bruno, A.V. (1984) 'A model of venture capitalist investment activity', Management Science, Vol. 30, No. 9, pp.1051-1066.

United Nations (UN) (1992) Agenda 21, Chap. 9.9, http://www.un.org/esa/sustdev/documents/ agenda21/english/agenda21toc.htm.

United Nations Development Programme (UNDP)/World Energy Council (WEC)/United Nations Department of Economic and Social Affairs (UNDESA) (2000) World Energy Assessment, New York, http://www.undp.org/seed/eap/activities/wea/.

Venkataraman, S. (2004) 'Regional transformation through technological entrepreneurship', Journal of Business Venturing, Vol. 19, No. 1, pp.153-167.

Wright, M. and Robbie, K. (1998) 'Venture capital and private equity: a review and synthesis', Journal of Business Finance and Accounting, Vol. 25, Nos. 5-6, pp.521-570.

Wüstenhagen, R. (2000) 'Ökostrom - vonder Nische zum Massenmarkt (Green electricity - from niche to mass markets), Entwicklungsperspektiven und Marketingstategien für eine zukunftsfähige Elektrizitätsbranche,vdf-Verlag', Zürich; zugl. Dissertation, Universität St. Gallen 2000. 
Zacharakis, A.L. and Meyer, D.G. (1998) 'A lack of insight: do venture capitalists really understand their own decision process?', Journal of Business Venturing, Vol. 13, pp.57-76.

Zider, B. (1998) 'How venture capital works', Harvard Business Review, Vol. 76, No. 6, pp.131-140.

\section{Notes}

1 The term Private Equity is also sometimes used as a generic term including all stages of private financing from early-stage venture capital to late-stage pre-IPO investments. In this paper, however, we only look at venture capital and use the term Private Equity to describe late stage and buyout investments.

2 http://www.eia.doe.gov/pub/international/iea2002/table63.xls

3 http://www.eia.doe.gov/pub/international/iea2001/table18.xls

4 See for example SAM (2002) or Wüstenhagen (2000) for a more extensive discussion of sustainable energy technologies.

5 See for example a recent cover story of the US Venture Capital Journal (Henig, 2003).

6 See Sagar and Holdren (2002) for a similar argument about the difficulties in counting energy-relevant $R \& D$ expenditures.

7 http://www.europeanenergyfair.com

8 See for example Zacharakis and Meyer (1998,p.61) for an overview.

9 www.energetech.com.au

10 www.capstoneturbine.com

11 www.enginion.com

12 To fully assess the correlation between low levels of R\&D spending and venture capital investment in the energy sector, one would have to take other elements of the energy innovation system into account, such as technology transfer mechanisms, public and private funding for demonstration projects, university spin-offs, etc. - Cf. the analysis of Müller et al. (2004) on 'Sources of bioentrepreneruship' or Venkataraman's (2004) discussion of the 'Seven intangibles of regional technological entrepreneurship'.

13 A particularly innovative proposal for managing people risk in the selection phase comes from one of the VCs interviewed by Fried and Hisrich (1994) proposing to visit the entrepreneur at home: "I like to go out and meet the spouse and the kids and try to see if their home is in chaos or if it's pretty orderly".

14 See for example Barry et al. (Wright and Robbie, 1998), Gompers and Lerner (BVK, 2003) and Lange et al. (2001).

15 In a sample of 433 VC-backed IPOs in the 1978-1987 time period, Barry et al. (1990) found that VCs had only reduced their shareholdings by an average $28 \%$ one year after the IPO.

16 See Kaplan and Schoar (2004) for an extensive discussion about IRR and alternative performance measures for venture capital funds.

17 We acknowledge that by assuming an exit at IPO plus 180 days, and given the negative share price development for these companies since then, we probably overestimate actual returns to a certain extent. Also, transaction cost for liquidating the investment is not included in our analysis.

18 This is confirmed by the results of two recent analyses with larger samples. Logerfo (2005) looked at 800 exits of cleantech ventures, including energy technology, and demonstrated favourable returns both for trade sales and IPOs. Moore (2005) investigated a sample of 88 energy technology IPOs in the 1996-2004 period and came to similar conclusions.

19 See the following references for a discussion of the concept of path dependencies in various disciplines of the social sciences: Pierson (2000), North (1990) and Goldstone (1998).

20 This seems to be the conclusion from population ecology approaches to explaining growth of the VC market in several European countries, see for example Manigart (1994). 